\title{
Editorial
}

\section{Welcome to discover water}

\author{
James LaMoreaux ${ }^{1}$
}

(c) The Author(s) 2021 OPEN

Dear Readers, Reviewers, Authors, and Editors,

In our announcement of the launch of Discover Water, we emphasized the need for rapid publication and open access to introduce scholarly peer-reviewed work to the scientific community in a timely manner. This is vital in order to place state-of-the-art water research into the mainstream for discussion purposes as demand grows for the same.

To further this aim, the journal also encourages forward looking and/or speculative opinion pieces that present a balanced view of a topic. In this way, discussion is stimulated, and new approaches are explored and supported by case studies and examples of novel research. Another important aim is to support and accelerate the United Nations Sustainable Development Goal Six: Clean Water and Sanitation.

The first article is being published as you read this. In addition, several topical collections have been announced: Impacts of Large Storm events on Water Resource and Supply; The Nature-Based Solutions and Circularity Practices at Water Management; and Ecosystem Restoration through Ecosystem Based Adaptation Approach.

An excellent and diverse team of Associate Editors and Editorial Board Members has been assembled from around the world. New members are continuing to be selected to add to this esteemed group of professionals. New topical collections are being solicited from them and from our readers as a whole. Please keep us in mind for hot topics of widespread interest that you may be interested in exploring on different aspects related to water.

Sincerely,

$\operatorname{Jim}$

Dr. Jim LaMoreaux

Editor in Chief Discover Water.

Chairman PELA GeoEnvironmental

Authors' contributions The author read and approved the final manuscript.

Competing interests The author declares that he has no competing interests.

Open Access This article is licensed under a Creative Commons Attribution 4.0 International License, which permits use, sharing, adaptation, distribution and reproduction in any medium or format, as long as you give appropriate credit to the original author(s) and the source, provide a link to the Creative Commons licence, and indicate if changes were made. The images or other third party material in this article are included in the article's Creative Commons licence, unless indicated otherwise in a credit line to the material. If material is not included in the article's Creative Commons licence and your intended use is not permitted by statutory regulation or exceeds the permitted use, you will need to obtain permission directly from the copyright holder. To view a copy of this licence, visit http://creativecommons.org/licenses/by/4.0/.

Publisher's Note Springer Nature remains neutral with regard to jurisdictional claims in published maps and institutional affiliations.

James LaMoreaux, JLamoreaux@pela.com | 'PELA GeoEnvironmental, Tuscaloosa, AL, USA.

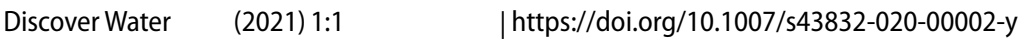

Published online: 11 January 2021 